\title{
The influence of breeding colony and sex on mercury, selenium and lead levels and carbon and nitrogen stable isotope signatures in summer and winter feathers of Calonectris shearwaters
}

\author{
Raül Ramos \& Jacob González-Solís \& \\ Manuela G. Forero \& Rocío Moreno \& \\ Elena Gómez-Díaz \& Xavier Ruiz \& Keith A. Hobson
}

\begin{abstract}
Contamination in marine foodwebs is nowadays of great environmental concern owing to the increasing levels of pollution in marine ecosystems from different anthropogenic sources. Seabirds can be used as indicators of regional contaminant patterns across large temporal and spatial scales. We analysed $\mathrm{Hg}$, Se and $\mathrm{Pb}$ levels as well as stable isotope ratios of $\mathrm{C}\left({ }^{13} \mathrm{C} /{ }^{12} \mathrm{C}, \mathrm{d}^{13} \mathrm{C}\right)$ and $\mathrm{N}\left({ }^{15} \mathrm{~N} /{ }^{14} \mathrm{~N}, \mathrm{~d}^{15} \mathrm{~N}\right)$ in breeding- and winter-season feathers on males and females of two related shearwater species, providing information on spatiotemporal patterns of contaminants as well as the influence of the trophic ecology of these seabirds on contaminant levels. During the breeding season, Se and $\mathrm{Pb}$ concentrations were highest at the Cape Verde archipelago, showing no differences among the other colonies or between the sexes. However, $\mathrm{Hg}$ levels varied among colonies, being highest in the Mediterranean, probably resulting from the larger emissions and fallout of this pollutant in Europe. Feathers
\end{abstract}

Xavier Ruiz: deceased 27 April 2008.

Communicated by Carlos Martinez del Rio.

R. Ramos (\&) · J. González-Solís · R. Moreno ·

E. Gómez-Díaz · X. Ruiz

Department de Biologia Animal (Vertebrats),

Facultat de Biologia, Universitat de Barcelona,

Av. Diagonal 645, 08028 Barcelona, Spain

e-mail: ramos@ub.edu

M. G. Forero

Department of Conservation Biology,

Estación Biológica de Doñana, Av. María Luisa,

s/n, Pabellón del Perú, 41013 Sevilla, Spain

K. A. Hobson

Environment Canada, 11 Innovation Blvd,

Saskatoon, SK S7N 3H5, Canada grown during breeding also showed sexual differences in $\mathrm{Hg}$ concentrations and $\mathrm{d}^{13} \mathrm{C}$. Differences in $\mathrm{Hg}$ concentration between sexes are mainly due to egg-laying decontamination in females. In contrast, differences in $\mathrm{Hg}$ among colonies are probably related to differences in trophic ecology, as indicated by $\mathrm{d}^{13} \mathrm{C}$ and $\mathrm{d}^{15} \mathrm{~N}$ measurements. Contaminant concentrations in winter-grown feathers did not show any relationship with stable isotope values but were affected by contaminant loads associated with the breeding season. These findings suggest that the interpretation of contaminant levels of migratory species from feathers moulted out of the breeding season should be made with caution because those values could reflect exposures to contaminants acquired during the breeding season. We conclude that factors other than feeding ecology may play an important role in the interpretation of contaminant levels and their annual dynamics at several spatial scales. Consideration of the relevant temporal context provided by isotopic signatures and contaminant concentrations is important in deciphering contaminant information based on various tissues.

Keywords Carbon-13 - Sealife contamination · Migratory connectivity · Nitrogen-15 .

Marine foodweb pollutants

Introduction

Oceans are increasingly becoming a repository for anthropogenic pollutants from aerial and aquatic sources and these are ultimately incorporated into the tissues of marine biota. Contamination discharges, however, are not spatially uniform and spatial differences in contaminant levels of marine organisms have been difficult to study 
because species composition also changes across ocean regions (e.g. Cherel and Hobson 2007). Pelagic seabirds can help us to understand spatiotemporal dynamics of pollutants because many species have vast breeding distributions and undergo long-distance migrations. Thus, these traits provide opportunities to compare pollutant levels among remote populations as well as between breeding and wintering areas. In addition, since pelagic seabirds cover huge areas while foraging, they are relatively insensitive to local sources of pollutants and thus become excellent bioaccumulative integrators of baseline levels (Walsh 1990; González-Solís et al. 2002).

In seabirds, several factors can contribute to body burdens of heavy metals, such as foraging area, dietary preferences, breeding and moult schedules, migratory habits, body size, and taxonomic influences on metabolism (Walsh 1990; Monteiro and Furness 1995). Among them, differences in feeding ecology have been reported as some of the most important factors explaining differences in contaminant levels among individuals of the same species (González-Solís et al. 2002), among localities (Sanpera et al. 2000), and also among species (Monteiro et al. 1999; González-Solís et al. 2002). Indeed, many seabird species occur at high trophic levels in marine foodwebs, which make seabirds useful indicators of biomagnification processes of some pollutants, such as $\mathrm{Hg}$ (e.g. Honda et al. 1987). However, relationships among pollutants and feeding ecology are difficult to establish because conventional dietary studies suffer from several drawbacks including analytical biases and difficulty of access to birds during winter (González-Solís et al. 1997). In this respect, stable isotope ratios of $\mathrm{N}\left({ }^{15} \mathrm{~N} /{ }^{14} \mathrm{~N}, \mathrm{~d}^{15} \mathrm{~N}\right)$ and $\mathrm{C}\left({ }^{13} \mathrm{C} /{ }^{12} \mathrm{C}, \mathrm{d}^{13} \mathrm{C}\right)$ open new opportunities to explore relationships between feeding ecology and heavy metal burdens (Forero and Hobson 2003; Sanpera et al. 2007). Consumers are typically enriched in ${ }^{15} \mathrm{~N}$ relative to their food and consequently $\mathrm{d}^{15} \mathrm{~N}$ measurements are indicators of their diet and trophic position (e.g. Forero et al. 2004). By contrast, $\mathrm{d}^{13} \mathrm{C}$ values are used primarily to determine sources of primary production supporting foodweb components (Kelly 2000); indicating in the marine environment, inshore versus offshore, or pelagic versus benthic contribution to food intake (Hobson et al. 1994).

However, despite the growing number of studies describing heavy metal levels and stable isotope abundance in seabirds (Atwell et al. 1998; Bearhop et al. 2000), few papers combine analyses of both to tackle spatial and seasonal variation in metal burdens and its relationship with variability in feeding ecology (but see Nisbet et al. 2002; Sanpera et al. 2007). Analyses of both stable isotopes and contaminant levels in feathers are particularly appropriate for this objective in those species for which main moult pattern and time of feather formation are known.
Once formed, feathers become chemically inert, and thus their biogeochemical composition reflects metals and isotopes incorporated during growth. If moulting patterns are known, feathers can be sampled at any time of the year to examine feeding habits and heavy metal intake in specific time periods and colonies (Hobson 1999). At least for Hg, plumage has greater levels than other tissues (Thompson et al. 1990), feather growth being the major eliminatory pathway of that heavy metal in birds (Monteiro and Furness 1995). However, while dietary elements, and so their stable isotope signatures, are thought to be promptly routed to growing feathers, heavy metal dynamics seem to be more complex and feathers may not accurately reflect contaminant loads during the time of growth (Thompson et al. 1998a).

In this study we analysed $\mathrm{Hg}$, Se and $\mathrm{Pb}$ concentrations and $\mathrm{d}^{13} \mathrm{C}$ and $\mathrm{d}^{15} \mathrm{~N}$ values in feathers from three related taxa of shearwater, the Mediterranean Cory's shearwater Calonectris diomedea diomedea, the Atlantic Cory's shearwater Calonectris diomedea borealis, and Cape Verde shearwater Calonectris edwardsii, breeding in the Mediterranean, the northeast Atlantic and the Cape Verde archipelago, respectively. We sampled birds from the Chafarinas, Azores, Canary and Cape Verde archipelagos and analysed contaminants and stable isotopes in the first primary feathers (P1) and the eighth secondary feathers (S8), which are thought to be grown at the breeding and wintering grounds, respectively (Ramos et al. 2008). With this sampling strategy we aimed to: (1) explore the geographic variability in heavy metals of shearwater feathers from four remote archipelagos and relate them to the geographic differences in emissions and discharges of these elements; (2) relate interspecific, sexual and individual differences in heavy metal levels to the trophic ecology of the Calonectris shearwaters, as shown by $\mathrm{d}^{15} \mathrm{~N}$ values; and (3) to study the dynamics of stable isotopes and heavy metals deposited in feathers by comparing feathers grown in breeding and wintering areas.

\section{Materials and methods}

Study species, study area and sampling strategy

Cory's shearwater C. diomedea is formed by two subspecies, C. d. diomedea breeding on islands in the Mediterranean, and C. d. borealis which breeds in the northeast Atlantic, from the Azores to the Canary archipelagos. The Cape Verde shearwater C. edwardsii, once considered a subspecies of Cory's shearwater, has recently been split off and it is currently considered as an endemic species of the Cape Verde Archipelago (Hazevoet 1995; Gómez-Díaz et al. 2006). This study included four different 
archipelagos: Chafarinas, Azores, Canary and Cape Verde Islands (Is.) (Fig. 1). The Chafarinas Is. are located at $4.5 \mathrm{~km}$ off the Moroccan Mediterranean coast $\left(35^{\circ} 11^{\circ} \mathrm{N}\right.$, $3^{\circ} 46^{\circ} \mathrm{E}$ ); Azores Is. at the North-Mid Atlantic Ocean (36$39^{\circ} \mathrm{N}, 25-31^{\circ} \mathrm{W}$ ), about $1,500 \mathrm{~km}$ west from the coast of Portugal; the Canary Is.. are about $120 \mathrm{~km}$ from the northwest African coast $\left(27-29^{\circ} \mathrm{N}, 13-18^{\circ} \mathrm{W}\right)$; and the Cape Verde Is. are located $500 \mathrm{~km}$ off the western coast of Senegal $\left(15-17^{\circ} \mathrm{N}, 23-25^{\circ} \mathrm{W}\right)$.

During the early breeding season of 2001, when adults were incubating eggs, we collected the P1 and S8 from 22 to 35 adult shearwaters at each locality (total $n=118$ ). Cory's and Cape Verde shearwater moult P1 at the end of chick-rearing period, before departing from the breeding grounds to the wintering areas (personal observation; Monteiro and Furness 1996). Thus, since feathers were collected during the breeding period of 2001, the P1 was assumed to reflect dietary intake at the end of the 2000 breeding period. A recent study on moulting patterns of secondary feathers in Cory's shearwaters showed some birds may start moulting S8 around the breeding colony just before migration (Ramos et al. 2008). However, that study was based on specimens accidentally caught in longliners and probably include non-breeders, which are known to moult earlier than breeders (Edwards 2008). The present study only includes breeding birds, and therefore S8 is expected to be moulted on the wintering grounds. In addition to feathers, $0.5 \mathrm{ml}$ blood was taken from the foot vein for further molecular sexing of individuals as described by Ellegren et al. (1996) (primers: 2550F and 2718R).

Sample preparation and laboratory analyses

At the laboratory, feathers were washed in a $0.25 \mathrm{M} \mathrm{NaOH}$ solution, rinsed thoroughly in distilled water to remove any

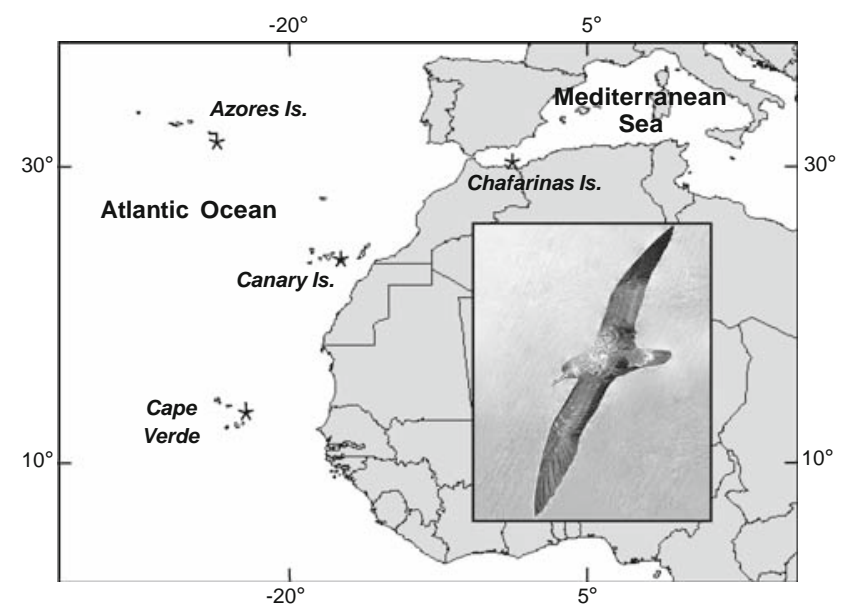

Fig. 1 Location of the studied area. Asterisks indicate archipelagos where samples were taken (original illustration from Ole Krogh) surface contamination, dried in an oven at $60^{\circ} \mathrm{C}$ to constant mass, and ground to a fine powder in a freezer mill (Spex Certiprep 6750; Spex, Metuchen, N.J.) operating at liquid $\mathrm{N}$ temperature. For stable isotope analyses, a subsample of $0.4 \mathrm{mg}$ feather powder was weighed to the nearest microgram, placed into tin capsules and crimped for combustion. Samples were oxidized in a Flash EA1112 coupled to a stable isotope mass spectrometer (Delta C) through a Conflo III interface (ThermoFinnigan, Bremen, Germany), where the $\mathrm{d}^{15} \mathrm{~N}$ and $\mathrm{d}^{13} \mathrm{C}$ values were determined. Isotope ratios are expressed conventionally as $\mathrm{d}$ values in parts per thousand (\%) according to the following equation:

$\mathrm{dX}^{1 / 4}{ }^{\circ} \mathrm{R}_{\text {sample }}=\mathrm{R}_{\text {standard }}{ }^{\circ}-1^{\circ} \times 1000$

where $\mathrm{X}(\%)$ is ${ }^{13} \mathrm{C}$ or ${ }^{15} \mathrm{~N}$ and $\mathrm{R}$ is the corresponding ratio $\left({ }^{13} \mathrm{C} /{ }^{12} \mathrm{C}\right.$ or $\left.{ }^{15} \mathrm{~N} /{ }^{14} \mathrm{~N}\right)$, related to the standard values. $\mathrm{R}_{\text {standard }}$ for ${ }^{13} \mathrm{C}$ is Pee Dee belemnite and for ${ }^{15} \mathrm{~N}$ is atmospheric $\mathrm{N}$ (AIR). Isotopic ratio mass spectrometry facility at the Serveis Científico-Tècnics of University of Barcelona applies international standards (IAEA $\mathrm{CH}_{7}$, IAEA $\mathrm{CH}_{6}$ and USGS 24 for $\mathrm{C}$ and IAEA N1, IAEA N2 and IAEA $\mathrm{NO}_{3}$ for $\mathrm{N}$ ) inserted every 12 samples to calibrate the system and compensate for any drift over time. Replicate assays of standard materials indicated measurement errors of \pm 0.1 and $\pm 0.2 \%$ for $\mathrm{C}$ and $\mathrm{N}$, respectively, but these are likely underestimates of true measurement error for complex organics like feathers.

To determine concentrations of $\mathrm{Pb}, \mathrm{Hg}$ and $\mathrm{Se}, 50 \mathrm{mg}$ feather powder was digested in $1 \mathrm{ml} \mathrm{HNO}_{3}(69-70 \%)$ and $0.5 \mathrm{ml} \mathrm{H}_{2} \mathrm{O}_{2}$ (30\%) using Teflon bombs for $12 \mathrm{~h}$ at $60^{\circ} \mathrm{C}$. The result of the digestion was diluted into $7 \mathrm{ml}$ distilled water. Analyses were performed using an ICP-OES (Optima 3200 RL; Perkin Elmer, Norwalk, Conn.). Accuracy of analysis was checked by measuring certified reference material (human hair CRM 397; Community Bureau of Reference, Commission of the European Community). To check the reproducibility of the procedure, we included sample replicates as well as negative controls in each set of samples analysed.

\section{Statistical analyses}

Distributions of $\mathrm{d}^{13} \mathrm{C}, \mathrm{d}^{15} \mathrm{~N}$, Se, $\mathrm{Pb}$ and $\mathrm{Hg}$ values partitioned by colony were inspected with a $\mathrm{Q}-\mathrm{Q}$ plot analysis and tested for normality. Then, $\mathrm{Se}, \mathrm{Pb}$ and $\mathrm{Hg}$ concentration values were log transformed to reach normality. Analyses of variability of contaminants and stable isotopes at breeding and wintering grounds were performed by applying separated generalized linear mixed models (GLMM; Littell et al. 1996). Species identity was treated as a random term in the GLMMs using SAS Macro program GLIMMIX (Littell et al. 1996). When each contaminant level during breeding (measured in P1) was the response 
variable we tested the main effects and interactions of breeding colony, sex and stable isotopes (as an estimation of feeding ecology during breeding). When response variables were levels of contaminants during winter (measured in S8), we also considered the potential effect of breeding colony, sex, stable isotope signatures at wintering and levels of stable isotopes and contaminants at breeding grounds (measured in P1). Contaminant levels in P1 were fitted to control for the potential effects of the accumulation of heavy elements during the breeding season but being excreted at a later stage (i.e. throughout the winter moult period). All main effects of the explanatory variables and their interactions were also fitted to the observed data.

For a better understanding of the influence of feeding ecology on contaminant levels in our study species, the same statistical procedure was used to analyse variability in stable isotope values at breeding and wintering grounds. In addition to the random effect of species, breeding colony, sex and their interaction were fitted to the observed stable isotope values. Stable isotope values of P1 were also fitted in the models for $\mathrm{d}^{15} \mathrm{~N}$ and $\mathrm{d}^{13} \mathrm{C}$ values in S8. In all cases, the final selected model was built following a forward stepwise procedure which includes only the significant effects retained.

Results

Breeding season

Considering levels of $\mathrm{Hg}$ in $\mathrm{P} 1$, and after controlling for species, the GLMM explained up to $64.2 \%$ of the initial variance and included three main explanatory variables: $\mathrm{d}^{15} \mathrm{~N}$ in $\mathrm{P} 1\left(\mathrm{~F}_{1,91}=18.6, \mathrm{P} \backslash 0.0001\right)$, sex $\left(\mathrm{F}_{1,91}=12.7\right.$, $\mathrm{P}=0.0006)$, and breeding colony $\left(\mathrm{F}_{3,91}=46.83\right.$, $\mathrm{P} \backslash 0.0001)$. Males exhibited higher levels of $\mathrm{Hg}$ than females (Fig. 2). Differences among colonies were mainly caused by the highest and lowest values of $\mathrm{Hg}$ at the Chafarinas and Cape Verde Is., respectively (Fig. 2a). Levels of Hg were positively related to $\mathrm{d}^{15} \mathrm{~N}$ value (Fig. 3). The best-fit models for $\mathrm{Se}$ and $\mathrm{Pb}$ burdens during breeding explained 48.1 and $35.9 \%$ of the initial variation, respectively, and only retained the significant effect of breeding colony $\left(\mathrm{Se}, \mathrm{F}_{3,112}=24.59, \mathrm{P} \backslash 0.0001 ; \mathrm{Pb}, \mathrm{F}_{3,112}=20.92\right.$,
Fig. 2 Mean and 95\% intervals of confidence (IC) of pollutant concentrations (a Hg, b Se, $\mathrm{c} \mathrm{Pb}$ ) and stable $\mathrm{C}(\mathrm{d})$ and $\mathrm{N}$ isotope (e) in first primary (P1; filled symbols) and eighth secondary feathers (S8; empty symbols) of Cape Verde and Cory's shearwaters [Cape Verde (CV; triangles), Azores Is. (A; diamonds), Canary Is. (C; squares) and Chafarinas Is. (Ch; circles)]. Mean values of males (asterisks) and females (dots) are also shown for every colony when sexual differences were significant or marginally non-significant. Sample sizes are shown in parentheses (n)

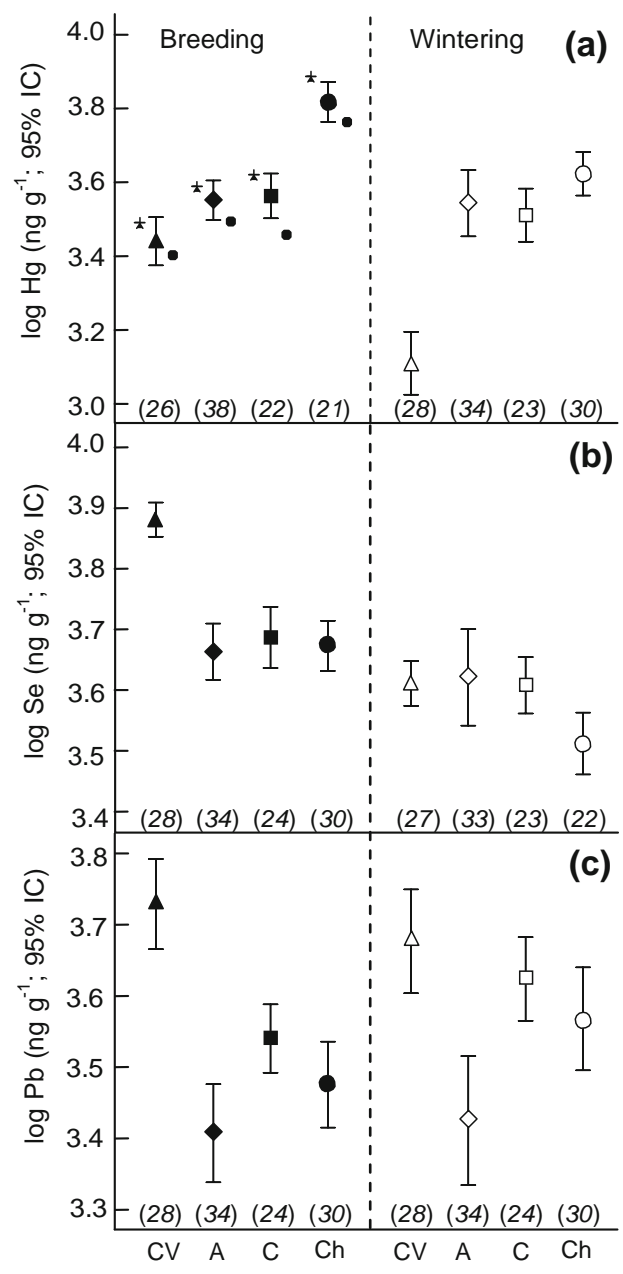

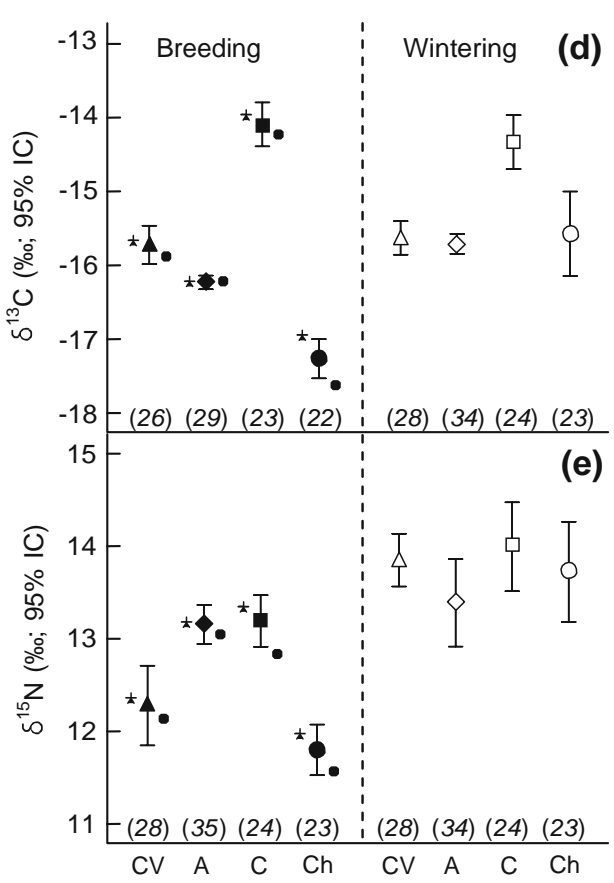




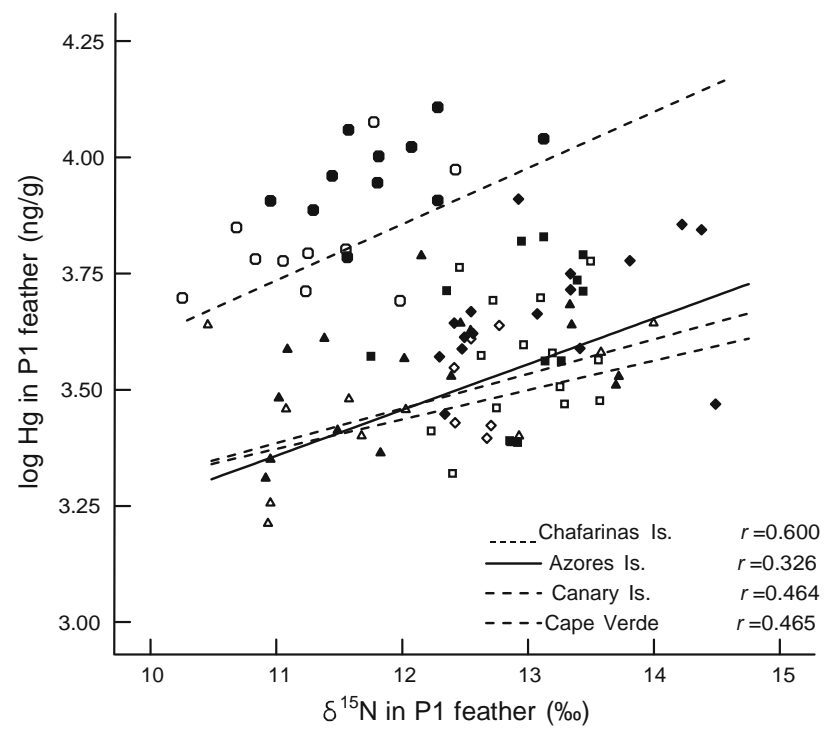

Fig. 3 Relationship between stable $\mathrm{N}$ isotope and Hg concentration in P1. Linear regressions are shown for each breeding locality separately: Cape Verde (triangles), Azores Is. (diamonds), Canary Is. (squares) and Chafarinas Is. (circles). Males represented by filled symbols and females by empty symbols

$\mathrm{P} \backslash 0.0001)$. Effect of breeding colony was explained by the elevated values of $\mathrm{Se}$ and $\mathrm{Pb}$ in individuals from the Cape Verde archipelago, whereas values for the rest of the localities were similar (Fig. 2b, c).

Regarding stable isotopes during breeding, variability in $\mathrm{d}^{13} \mathrm{C}$ values (range: -18.5 to $-12.4 \%$ ) was larger than in $\mathrm{d}^{15} \mathrm{~N}$ values (range: 10.5-14.7\%). After controlling for species, models explained 80.1 and $45.0 \%$ of the original deviance in $\mathrm{d}^{13} \mathrm{C}$ and $\mathrm{d}^{15} \mathrm{~N}$, respectively. Both models included the significant effect of breeding colony $\left(\mathrm{d}^{13} \mathrm{C}, \quad \mathrm{F}_{3,95}=119.86, \mathrm{P} \backslash 0.0001 ; \mathrm{d}^{15} \mathrm{~N}, \quad \mathrm{~F}_{3,106}=19.85\right.$, $\mathrm{P} \backslash 0.0001)$. All colonies differed in their $\mathrm{d}^{13} \mathrm{C}$ values: individuals from the Canary Is. showed the highest $\mathrm{d}^{13} \mathrm{C}$ values, whereas those from the Chafarinas showed the lowest (Fig. 2d). Birds from the Azores and Canary Is. presented higher $\mathrm{d}^{15} \mathrm{~N}$ values than individuals from the Chafarinas and Cape Verde Is. (Fig. 2e). During breeding, males showed consistently higher values of stable $\mathrm{d}^{15} \mathrm{~N}$ and $\mathrm{d}^{13} \mathrm{C}$ values than females. However, sex was only significantly retained in the model of $\mathrm{d}^{13} \mathrm{C}$ values $\left(\mathrm{F}_{1,95}=4.55\right.$, $\mathrm{P}=0.03$; Fig. 2d), being marginally non-significant for $\mathrm{d}^{15} \mathrm{~N}$ values $\left(\mathrm{F}_{1,95}=3.00, \mathrm{P}=0.09\right)$.

\section{Wintering season}

Results of the GLMM showed different effects of the explanatory variables on levels of contaminants during winter (measured in S8), explaining 52.8, 21.9 and 37.2\%, respectively, for $\mathrm{Hg}$, Se and $\mathrm{Pb}$. In the three models, and after controlling for species, levels of contaminants in S8 were significantly and positively affected by their respective values in $\mathrm{P} 1$ during breeding $\left(\mathrm{Hg}, \mathrm{F}_{1,110}=12.92\right.$, $\mathrm{P}=0.0005 ;$ Se, $\mathrm{F}_{1,99}=8.19, \mathrm{P}=0.005 ; \mathrm{Pb}, \mathrm{F}_{1,111}=$ 42.85, $\mathrm{P} \backslash 0.0001)$. In addition, colony also influenced levels of $\mathrm{Hg} \quad\left(\mathrm{F}_{3,110}=19.12, \quad \mathrm{P} \backslash 0.0001\right)$ and $\mathrm{Se}$ $\left(\mathrm{F}_{3,99}=2.90, \mathrm{P}=0.04\right)$ during winter: individuals that bred at Cape Verde and the Chafarinas showed the lowest levels of $\mathrm{Hg}$ and Se during winter, respectively (Fig. 2a, b). Finally, levels of Se were negatively affected by the $\mathrm{d}^{15} \mathrm{~N}$ value in $\mathrm{S} 8\left(\mathrm{~F}_{1,99}=10.85, \mathrm{P}=0.00014\right)$.

When analysing variability in feeding ecology during winter, we did not find any significant effect of the explanatory variables on feather $\mathrm{d}^{15} \mathrm{~N}$ values, after controlling for species. The GLMM for feather $\mathrm{d}^{13} \mathrm{C}$ explained $36.4 \%$ of the original deviance and showed that its variability during winter was explained by $\mathrm{d}^{13} \mathrm{C}$ values of $\mathrm{P} 1$ $\left(F_{1,104}=7.73, \quad P=0.0064\right)$ and colony $\left(F_{3,104}=5.09\right.$, $\mathrm{P}=0.0025)$. Effect of $\mathrm{d}^{13} \mathrm{C}$ values of $\mathrm{P} 1$ was only due to the positive correlation between $\mathrm{d}^{13} \mathrm{C}$ values of $\mathrm{P} 1$ and $\mathrm{S} 8$ at the Canary archipelago (Fig. 4). In addition, high $\mathrm{d}^{13} \mathrm{C}$ values of individuals that bred at this archipelago (Fig. 2d) explained the significance of breeding colony.

\section{Discussion}

Differences in $\mathrm{Hg}$, Se and $\mathrm{Pb}$ among colonies and sexes

Although contaminant levels of the sampled colonies differed, they were generally similar to those previously reported for Cory's shearwater throughout the Mediterranean and Mid Atlantic Ocean (Renzoni et al. 1986; Monteiro et al. 1999). In particular, Monteiro et al. (1999) reported body feather $\mathrm{Hg}$ concentrations of Cory's shearwaters from several Mid-Atlantic colonies sampled in 1993-1995 ranging between 3.54 and $3.85 \mathrm{ng} \mathrm{g}^{-1}$, which are close to the results we found for this area. Thus, in spite of the current environmental concern about the increasing oceanic pollution from anthropogenic sources, we found heavy metal and Se levels in seabird feathers not greater than those previously reported a decade ago (Thompson et al. 1992; Elliott et al. 1992; Sanpera et al. 2000; Arcos et al. 2002).

Our results corroborate the importance of understanding excretion routes to evaluate contaminant concentrations in marine organisms. Hg presented a more complex dynamic than $\mathrm{Se}$ and $\mathrm{Pb}$, as shown by its additional association with stable isotope signatures and by the differences in levels between sexes. Dissociation between stable isotope signatures and Se or $\mathrm{Pb}$ levels could result from stable isotopes being deposited through dietary intake, whereas Se and $\mathrm{Pb}$ could have been deposited directly from the atmosphere onto the bird plumage (Rose and Parker 1982; Furness 1993). A number of studies with terrestrial birds reported 
that $\mathrm{Pb}$ levels increase as feathers age or are more exposed than those lying under other plumage (e.g. Hahn 1991). Although Se may also deposit onto feather surfaces, it may originate from preen oils as well (Goede 1991). In contrast, $\mathrm{Hg}$ in feathers comes from diet because it occurs in the methyl-Hg form, whereas elemental and inorganic Hg are highly volatile and do not deposit onto feather surfaces (Thompson and Furness 1989). Alternatively, the lack of association of Se and $\mathrm{Pb}$ levels with stable isotopes could simply be due to different Se and $\mathrm{Pb}$ baseline levels among local foodwebs. A significant effect of breeding colony on Se and $\mathrm{Pb}$ concentrations in $\mathrm{P} 1$ was due to the high values of these elements in shearwaters from Cape Verde, which probably resulted from greater baseline levels of these two elements in this area. In fact, a much greater particulate $\mathrm{Pb}$ concentration in surface seawater around Cape Verde than around the Canary or Azores archipelagos was reported from a cruise in the Atlantic Ocean (Helmers 1996). Likewise, in a cruise transect between the Azores and Cape Verde, the total dissolved Se only varied slightly in surface waters but was significantly greater in deep waters around the Cape Verde archipelago (Cutter and Cutter 1995). Both studies concluded that concentrations of $\mathrm{Pb}$ and Se were mainly affected by local inputs from upwelling and atmospheric deposition, supporting the importance of baseline levels as a major factor influencing the dynamics of these two elements in local foodwebs. In the case of $\mathrm{Hg}$, the highest levels were found in individuals from the Mediterranean colony (Chafarinas Is.; Fig. 2a). This result is probably related to the emissions and discharges of this pollutant in Europe, generating a relatively high $\mathrm{Hg}$ levels in the Mediterranean compared to the Atlantic, as previously reported in a number of studies on several top predators species (Renzoni et al. 1986; Andre et al. 1991; Lahaye et al. 2006). On the other hand, the greater levels of $\mathrm{Hg}$ and $\mathrm{d}^{15} \mathrm{~N}$ values found in the Azores and Canary shearwaters compared to Cape Verde shearwaters suggest a geographic variation in baseline isotopic and contaminant levels. A differential use of fishery discards may also explain some differences, since discarded mesopelagic fish show greater $\mathrm{Hg}$ burden than the readily accessible epipelagic fish (Thompson et al. 1998b). However, in this case shearwaters from the Canary Is. should show greater $\mathrm{Hg}$ levels than those from the Azores due to their proximity to the trawler fleet operating on the western Africa continental shelf, but this was not the case.

In addition to the $\mathrm{Hg}$ variability associated with differences in $\mathrm{d}^{15} \mathrm{~N}$ values among colonies, levels of $\mathrm{Hg}$ during breeding were also associated with individual $\mathrm{d}^{15} \mathrm{~N}$ values within each locality (Fig. 3). This result indicated that biomagnification processes not only occur across species through the foodweb (e.g. Honda et al. 1987), but also among individuals at the intraspecific level.
The importance of excretion routes for the Hg concentration was further corroborated by sexual differences in isotopic signatures and $\mathrm{Hg}$ concentration. Male shearwaters showed slightly but significantly higher levels of $\mathrm{Hg}$ than females, consistent throughout the four studied colonies (Fig. 2a), even when accounting for potential differences in the trophic levels of the prey consumed by males and females, as indicated by the $\mathrm{d}^{15} \mathrm{~N}$ values. This result agrees with some seabird studies, which also reported sexual differences in $\mathrm{Hg}$ levels in wing feathers (Braune and Gaskin 1987; Lewis et al. 1993), and probably reflects the different excretion opportunities of males and females. The main excretion route for both sexes is the deposition of $\mathrm{Hg}$ into feathers during moulting periods. Nevertheless, females have an additional route due to the potential to excrete Hg into the eggs between moulting periods (Becker 1992; Lewis et al. 1993; Monteiro and Furness 1995), which could further deplete their $\mathrm{Hg}$ levels relative to males (see Lewis and Furness 1993). Sexual differences in Hg levels could also be partly amplified by the slightly greater trophic level of males, as indicated by their greater $\mathrm{d}^{15} \mathrm{~N}$ values, although differences in $\mathrm{d}^{15} \mathrm{~N}$ values between sexes were not significant $(\mathrm{P}=0.09$, Fig. $2 \mathrm{e}$ ). Sexual size dimorphism in these species is relatively small, with males being only 5-9\% greater in bill and $9-10 \%$ greater in body mass than females (Thibault et al. 1997; Gómez-Díaz and González-Solís 2007; Navarro et al. 2008). Nevertheless, the slightly larger size of males may also confer access to slightly larger prey (see Bearhop et al. 2006) with both greater $\mathrm{d}^{15} \mathrm{~N}$ values and greater $\mathrm{Hg}$ content (Braune 1987; Monteiro et al. 1992; Badalamenti et al. 2002; Cherel and Hobson 2005).

Feathers moulted in winter showed a general decrease in $\mathrm{Hg}$ and Se concentrations and similar levels of $\mathrm{Pb}$ coupled with a carry-over effect from concentrations accumulated during the breeding period (Fig. 2a-c). On one hand, the decrease in $\mathrm{Hg}$ and Se concentrations can be explained by the moult of flight feathers which is a continuous and steady process from the first moulted feather (i.e. P1) until all flight feathers are replaced. Consequently, birds excrete more metals in the first moulted feather compared with subsequent feathers (i.e. eighth secondary) (Braune and Gaskin 1987; Walsh 1990). On the other hand, the carry-over effect is interesting because it shows the complex dynamics of $\mathrm{Hg}$, Se and $\mathrm{Pb}$. That is, their concentrations in feathers grown at their winter quarters (eighth secondary) were partly explained by concentrations of feathers grown at the breeding grounds (P1). In consequence, contaminant levels of migratory species from feathers moulted out of the breeding season should be interpreted with caution because these values could reflect exposure to contaminants during the breeding season, and vice versa (see Thompson et al. 1992). Therefore, a fraction of contaminant burdens in 
feathers has an endogenous origin, i.e. it is partially mobilized from various organs in which metals are stored (Goede 1991; Furness 1993). The deposition of contaminants acquired at breeding grounds on feathers grown out of the breeding period may be particularly important in procellariiform species, because they show long breeding seasons and relatively short wintering periods (Thompson et al. 1998a; Monteiro et al. 1999). For example, on average, Cory's shearwater spends 243 days at the breeding grounds, 80 days on the wintering grounds and 42 days travelling between the two areas (González-Solís et al. 2007). Alternatively to the carry-over effect, it is also possible that slight individual differences in physiology affect equally the efficiency with which birds excrete pollutants into the feathers throughout the moult sequence (Bearhop et al. 2000). However, such differences in individual physiology are generally considered irrelevant in influencing intraspecific variability in tissue pollutant concentrations (Becker et al. 2002; Nisbet et al. 2002). In addition, individual dietary specialisation could also explain an effect of contaminant levels during breeding on winter feathers. However, in that case it should be also observed in stable isotope levels, but in the present study $\mathrm{d}^{15} \mathrm{~N}$ signatures did not show any correlation between P1 and S8. Therefore, it seems reasonable to rule out any possible trophic reason for this phenomenon. Another possible explanation was that concentrations of $\mathrm{Hg}$, Se and $\mathrm{Pb}$ in the eighth secondary feather could also result from this feather being moulted at the breeding instead of the wintering grounds. It has been shown that some Cory's shearwaters moulting S8 before migration (Ramos et al. 2008). Although these birds are probably nonbreeders, this possibility cannot be completely discounted, but results from stable isotope analyses suggest otherwise. Whereas breeding colony was a significant factor explaining $\mathrm{d}^{15} \mathrm{~N}$ values in $\mathrm{P} 1$, it was not significant for $\mathrm{d}^{15} \mathrm{~N}$ in S8, suggesting that the signal of breeding colony vanishes because birds mix in several wintering areas where they grow the eighth secondary feathers. In the case of $\mathrm{d}^{13} \mathrm{C}$ values, breeding colony and $\mathrm{P} 1 \mathrm{~d}^{13} \mathrm{C}$ values were significant factors for $\mathrm{d}^{13} \mathrm{C}$ in $\mathrm{S} 8$. However, this model explained much less variance (31.7\%) than the model for $\mathrm{d}^{13} \mathrm{C}$ values of $\mathrm{P} 1$ (80.1\%), suggesting rather weak effects of breeding colony on wintering $\mathrm{d}^{13} \mathrm{C}$ values. In fact, the influence of the breeding colony and the positive effect of $\mathrm{d}^{13} \mathrm{C}$ in $\mathrm{P} 1$ on $\mathrm{d}^{13} \mathrm{C}$ values of $\mathrm{S} 8$ mainly resulted from birds breeding at the Canary Is. (Fig. 4). This relationship could be explained because some birds from this breeding colony seem to winter on the Sahara shelf (González-Solís et al. 2007), the same area where they feed during the breeding season (see below). Thus, in contrast to the endogenous origin of $\mathrm{Se}, \mathrm{Pb}$ and $\mathrm{Hg}$ burdens, stable isotope signatures of feathers reflect an exogenous origin, i.e. they are promptly routed to feathers when growing (Hobson 1999).

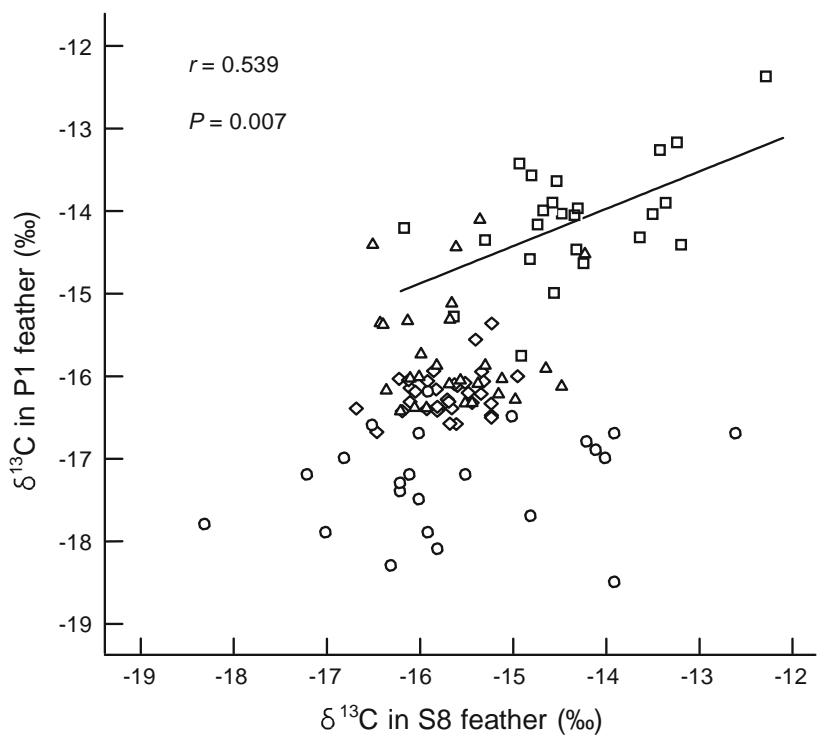

Fig. 4 Relationship between stable C isotopes for P1 and S8 are shown separately for each colony [Cape Verde (triangles), Azores Is. (diamonds), Canary Is. (squares) and Chafarinas Is. (circles)]. Only the regression line of the significant correlation for the colony on the Canary Is. is shown. For abbreviations, see Fig. 2

Differences in feeding ecology among colonies and sexes

Results from stable isotope analyses illustrated differences in the feeding ecology among different populations during breeding. Stable C isotope values of shearwaters breeding at the Canary Is. were higher than those of the other populations (Fig. 2d). Shearwaters breeding at the Canary Is. usually forage on the Sahara shelf at only $100-300 \mathrm{~km}$ from the islands (Navarro and González-Solís 2007), whereas those breeding at the Azores and Cape Verde Is. are expected to feed basically in offshore environments during the breeding season (Fig. 1; Magalhães et al. 2008). These results are therefore in accordance with most literature showing that offshore foodwebs have lower $\mathrm{d}^{13} \mathrm{C}$ values than those associated with inshore areas (France 1995; Hobson et al. 1995). Alternatively, such differences in $\mathrm{d}^{13} \mathrm{C}$ values could be due to a distinct use of fishery discards among colonies, since fisheries are mainly dominated by inshore or on-shelf species with greater $\mathrm{d}^{13} \mathrm{C}$ signatures. Differences in $\mathrm{d}^{13} \mathrm{C}$ values could also result from geographical variation in baseline values related to latitudinal gradients (Forero et al. 2005; Cherel and Hobson 2007). Indeed, analyses of feathers throughout most Calonectris populations in the Atlantic have shown some geographical isotope gradients in $\mathrm{d}^{13} \mathrm{C}$ values, with higher values in populations further south (Gómez-Díaz and González-Solís 2007). However, the Cape Verde archipelago is further south than the Canary Is. but showed more negative values, suggesting that the higher $\mathrm{d}^{13} \mathrm{C}$ values of 
birds from the Canary Is. cannot be only explained by latitudinal gradients.

Small but consistent differences in $\mathrm{d}^{13} \mathrm{C}$ values between the sexes may result from a vertical or a horizontal gradient in foodweb $\mathrm{d}^{13} \mathrm{C}$ values, indicating respectively, a slightly different exploitation of resources along the water column or differences in the foraging areas used by males and females during the breeding season. Sexual differences in $\mathrm{d}^{13} \mathrm{C}$ values were consistent with both greater Hg concentrations and $\mathrm{d}^{15} \mathrm{~N}$ values (although $\mathrm{P}=0.09$ ) in males during breeding, as previously found in some size-dimorphic Procellariiformes (González-Solís et al. 2000; Phillips et al. 2004; Forero et al. 2005; but see Navarro et al. 2008). In large- and medium-sized pelagic seabirds, larger body size has been related to diving longer and deeper (Watanuki and Burger 1999; Bearhop et al. 2006) as well as with greater wing-loading due to allometric relationships (Shaffer et al. 2003), which allows birds to cover longer distances in the presence of strong winds, probably leading to small differences in the areas exploited by males and females. Sexual differences found in both contaminant and isotopic levels could be imposed by differential reproductive tasks during breeding, and especially during the chickrearing period (Granadeiro et al. 1998), when foraging areas and resources could be exploited differentially by males and females. In fact, a slightly larger use of fishery discards by males at this period could explain such higher values in both stable isotopes and contaminant concentrations (Hobson et al. 1994; Thompson et al. 1998b). The sex-specific reproductive task hypothesis is supported by the fact that sexual differences did not hold for feathers grown in winter as there are no reproductive constraints at that time. Moreover, the mixing of birds from distant breeding colonies with different contaminant burdens into different winter areas (González-Solís et al. 2007) with different baseline heavy metal loads could mask any potential sexual differences in feeding ecology occurring in winter.

This study emphasizes that combining contaminant with stable isotope analyses provides new insights into the dynamics of contaminants in relation to the feeding ecology of marine organisms. Whereas differences in background levels among localities and/or deposition directly from the atmosphere seem to mostly explain $\mathrm{Pb}$ and Se concentrations in feathers, the feeding ecology of shearwaters played a major role in explaining Hg concentrations. Furthermore, sexual segregation in feeding ecology and different reproductive constraints between males and females also seem to affect Hg concentrations. More studies exploring the relationships among stable isotope measurements and pollutants would help to elucidate the differential exposure of birds to pollutants in relation to their ecology. We also found $\mathrm{Hg}$, Se and $\mathrm{Pb}$ accumulated in one season could be transferred to feathers grown in another season. Future studies using feathers to assess the winter contaminant levels in birds with long breeding periods should consider the carry-over effects of contaminant loads that can occur between seasons. Thus, our results also highlight the need to consider the temporal context of isotopic signatures versus contaminant levels depending on the tissue chosen as well as their endogenous (bioaccumulated) or exogenous (dietary) origin. Nevertheless, for a better understanding of factors and processes explaining patterns of stable isotopes and contaminants in marine organisms, more detailed studies involving longterm monitoring of isotope ratios and contaminant loads or complementary approximations (i.e. tracked animals with some remote-sensing system) are needed.

Acknowledgments We thank C. Sanpera, J. Navarro, M. Martínez and J. L. Roscales for reviewing earlier drafts of the manuscript, P. López, C. F. López-Jurado, V. Neves, P. Calabuig, the association Amigos de las Pardelas, M. Igual and I. Afan for help in the field. We also are very grateful to GENA's personal as well as to OAPN, Cabildo de Gran Canaria, the Azores Government and the Direçao Geral do Ambiente of Cape Verde who provided logistical support and the necessary authorisations. R. Ramos was supported by a FPU grant of the Ministerio de Educación y Ciencia (MEyC) of Spain and J. González-Solís and M. G. Forero were supported by a contract of the Program Ramón y Cajal funded by the MEyC and Fondos FEDER. Financial support was provided by grants 2001SGR00091 and 2005SGR00744 from Generalitat de Catalunya and CGL 2006-01315/ BOS from MEyC. We declare that all experiments and protocols performed comply with the current Spanish laws. The shearwater drawn in Fig. 1 was adapted from an original illustration by Ole Krogh.

\section{References}

Andre J, Boudou A, Ribeyre F, Bernhard M (1991) Comparative study of mercury accumulation in dolphins (Stenella coeruleoalba) from French Atlantic and Mediterranean coasts. Sci Total Environ 104:191-209

Arcos JM, Ruiz X, Bearhop S, Furness RW (2002) Mercury levels in seabirds and their fish prey at the Ebro Delta (NW Mediterranean): the role of trawler discards as a source of contamination. Mar Ecol Prog Ser 232:281-290

Atwell L, Hobson KA, Welch HE (1998) Biomagnification and bioacumulation of mercury in an Arctic marine food web: insights from stable isotopes. Can J Fish Aquat Sci 55:11141121

Badalamenti F, D’Anna G, Pinnegar J, Polunin N (2002) Size-related trophodynamic changes in three target fish species recovering from intensive trawling. Mar Biol 3:561-570

Bearhop S, Phillips RA, Thompson DR, Waldron S, Furness RW (2000) Variability in mercury concentrations of great skuas Catharacta skua: the influence of colony, diet and trophic status inferred from stable isotope signatures. Mar Ecol Prog Ser 195:261-268

Bearhop S, Phillips RA, McGill R, Cherel Y, Dawson DA, Croxall JP (2006) Stable isotopes indicate sex-specific and long-term individual foraging specialisation in diving seabirds. Mar Ecol Prog Ser 311:157-164 
Becker PH (1992) Egg mercury levels decline with the laying sequence in charadriiformes. Bull Environ Contam Toxicol 48:162-167

Becker PH, González-Solís J, Behrends B, Croxall JP (2002) Feather mercury levels in seabirds at South Georgia: influence of trophic position, sex and age. Mar Ecol Prog Ser 243:261-269

Braune BM (1987) Mercury accumulation in relation to size and age of Atlantic herring (Clupea harengus harengus) from the southwestern Bay of Fundy, Canada. Arch Environ Contam Toxicol 16:311-320

Braune BM, Gaskin DE (1987) Mercury levels in Bonaparte's gulls (Larus philadelphia) during autumn molt in the Quoddy region, New Brunswick, Canada. Arch Environ Contam Toxicol 16:539-549

Cherel Y, Hobson KA (2005) Stable isotopes, beaks and predators: a new tool to study the trophic ecology of cephalopods, including giant and colossal squids. Proc R Soc B 272:1601-1607

Cherel Y, Hobson KA (2007) Geographical variation in carbon stable isotope signatures of marine predators: a tool to investigate their foraging areas in the Southern Ocean. Mar Ecol Prog Ser 329:281-287

Cutter GA, Cutter LS (1995) Behavior of dissolved antimony, arsenic, and selenium in Atlantic Ocean. Mar Chem 49:295-306

Edwards AE (2008) Large-scale variation in flight feather molt as a mechanism enabling biennial breeding in albatrosses. J Avian Biol 39:144-151

Ellegren H, Gustafsson L, Sheldon BC (1996) Sex ratio adjustment in relation to paternal attractiveness in a wild bird population. Proc Natl Acad Sci USA 93:11723-11728

Elliott JE, Scheuhammer AM, Leighton FA, Pearce PA (1992) Heavy metal and metallothionein concentrations in Atlantic Canadian seabirds. Arch Environ Contam Toxicol 22:63-73

Forero MG, Hobson KA (2003) Using stable isotopes of nitrogen and carbon to study seabird ecology: applications in the Mediterranean seabird community. Sci Mar 67:23-32

Forero MG, Bortolotti GR, Hobson KA, Donázar JA, Bertellotti M, Blanco G (2004) High trophic overlap within the seabird community of Argentinean Patagonia: a multiscale approach. J Anim Ecol 73:789-801

Forero MG, González-Solís J, Hobson KA, Donázar JA, Bertellotti M, Blanco G, Bortolotti GR (2005) Stable isotopes reveal trophic segregation by sex and age in the southern giant petrel in two different food webs. Mar Ecol Prog Ser 296:107-113

France RL (1995) Carbon-13 enrichment in benthic compared to planktonic algae: foodweb implications. Mar Ecol Prog Ser 124:307-324

Furness RW (1993) Birds as monitors of pollutants. In: Furness RW, Greenwood JJD (eds) Birds as monitors of environment change. Chapman \& Hall, London, pp 86-143

Goede AA (1991) The variability and significance of selenium concentrations in shorebird feathers. Environ Monit Assess 18:203-210

Gómez-Díaz E, González-Solís J (2007) Geographic assignment of seabirds to breeding origin: combining morphology, genetics, and biogeochemical analyses. Ecol Aplic 17:1484-1498

Gómez-Díaz E, González-Solís J, Peinado MA, Page RDM (2006) Phylogeography of Calonectris shearwaters using molecular and morphometric data. Mol Phyl Evol 41:322-332

González-Solís J, Oro D, Pedrocchi V, Jover L, Ruiz X (1997) Bias associated with diet samples in Audouin's gulls. Condor 99:773779

González-Solís J, Croxall JP, Wood AG (2000) Sexual dimorphism and sexual segregation in foraging strategies of northern giant petrels Macronectes halli during the incubation period. Oikos 90:390-398
González-Solís J, Sanpera C, Ruiz X (2002) Metals as bioindicators of geographic and trophic segregation in giant petrels Macronectes spp. Mar Ecol Prog Ser 244:257-264

González-Solís J, Croxall JP, Oro D, Ruiz X (2007) Trans-equatorial migration and mixing in the wintering areas of a pelagic seabird. Front Ecol Environ 5:297-301

Granadeiro JP, Burns MD, Furness RW (1998) Patterns of activity and burrow attendance in Cory's shearwater Calonectris diomedea as revealed by a novel logging technique. Ibis 140:458-466

Hahn E (1991) Schwermetallgehalte in Vogelfedern-ihre Ursache und der Einsatz von Federn standorttreuer Vogelarten im Rahmen von Bioindikationsverfahren. Berichte des Forschungszentrums, Julich

Hazevoet CJ (1995) The birds of the Cape Verde Islands. An annotated check list. British Ornithologist Union, London

Helmers E (1996) Trace metals in suspended particulate matter of Atlantic Ocean surface water $\left(40^{\circ} \mathrm{N}\right.$ to $\left.20^{\circ} \mathrm{S}\right)$. Mar Chem 53:51-67

Hobson KA (1999) Tracing origins and migration of wildlife using stable isotopes: a review. Oecologia 120:314-326

Hobson KA, Ambrose WG, Renaud PE (1995) Sources of primary production, benthic-pelagic coupling, and trophic relationships within the Northeast Water Polynya: insights from delta ${ }^{13} \mathrm{C}$ and delta ${ }^{15} \mathrm{~N}$ analysis. Mar Ecol Prog Ser 128:1-10

Hobson KA, Piatt JF, Pitocchelli J (1994) Using stable isotopes to determine seabird trophic relationships. J Anim Ecol 63:786-798

Honda K, Yamamoto Y, Tatsukawa R (1987) Distribution of heavy metals in Antarctic marine ecosystem. Proc NIPR Symp Polar Biol 1:184-197

Kelly JF (2000) Stable isotopes of carbon and nitrogen in the study of avian and mammalian trophic ecology. Can J Zool 78:1-27

Lahaye V, Bustamante P, Dabin W, Van Canneyt O, Dhermain F, Cesarini C, Pierce GJ, Caurant F (2006) New insights from age determination on toxic element accumulation in striped and bottlenose dolphins from Atlantic and Mediterranean waters. Mar Poll Bull 52:1219-1230

Lewis SA, Furness RW (1993) The role of eggs in mercury excretion by Quail Coturnix coturnix and the implications for monitoring mercury pollution by analysis of feathers. Ecotoxicology 2:55-64

Lewis SA, Becker PH, Furness RW (1993) Mercury levels in eggs, tissues and feathers of herring gulls Larus argentatus from the German Wadden sea coast. Environ Pollut 80:293-299

Littell RC, Milliken GA, Stroup WW, Wolfinger RD (1996) SAS system for mixed models. SAS Insitute, Cary

Magalhães MC, Santos RS, Hamer KC (2008) Dual-foraging of Cory's shearwaters in the Azores: feeding locations, behaviour at sea and implications for food provisioning of chicks. Mar Ecol Prog Ser 359:283-293

Monteiro LR, Furness RW (1995) Seabirds as monitors of mercury in the marine environment. Water Air Soil Pollut 80:851-870

Monteiro LR, Furness RW (1996) Molt of Cory's shearwater during the breeding season. Condor 98:216-221

Monteiro LR, Porteiro FM, Gonçalves JM (1992) Inter- and intraspecific variation of mercury levels in muscle of cephalopods from the Azores. Arquipelago Ser Cienc Nat 10:13-22

Monteiro LR, Granadeiro JP, Furness RW, Oliveira P (1999) Contemporary patterns of mercury contamination in the Portuguese Atlantic inferred from mercury concentrations in seabird tissues. Mar Environ Res 47:137-156

Navarro J, González-Solís J (2007) Experimental increase of flying costs in a pelagic seabird: effects on foraging strategies, nutritional state and chick condition. Oecologia 151:150-160

Navarro J, Kaliontzopoulou A, González-Solís J (2008) Sexual dimorphism in bill morphology and feeding ecology in Cory's shearwater (Calonectris diomedea). Zoology (in press) 
Nisbet ICT, Montoya JP, Burger J, Hatch JJ (2002) Use of stable isotopes to investigate individual differences in diets and mercury exposures among common terns Sterna hirundo in breeding and wintering grounds. Mar Ecol Prog Ser 242:267274

Phillips RA, Silk JRD, Phalan B, Catry P, Croxall JP (2004) Seasonal sexual segregation in the two Thalassarche albatross species: competitive exclusion, reproductive role specialization or foraging niche divergence? Proc R Soc B 271:1283-1291

Ramos R, Militão T, González-Solís J, Ruiz X (2008) Moulting strategies of a long-distance migratory seabird: the Mediterranean Cory's Shearwater. Ibis (in press)

Renzoni A, Focardi S, Fossi C, Leonzio C, Mayol J (1986) Comparison between concentrations of mercury and other contaminants in eggs and tissues of Cory's shearwater Calonectris diomedea collected on Atlantic and Mediterranean islands. Environ Pollut (Ser A) 40:17-35

Rose GA, Parker GH (1982) Effects of smelter emissions on metal levels in the plumage of ruffed grouse near Sudbury, Ontario, Canada. Can J Zool 60:2659-2667

Sanpera C, Morera M, Ruiz X, Jover L (2000) Variability of mercury and selenium levels in clutches of Audouin's gulls (Larus audouinii) breeding at the Chafarinas Islands, Southwest Mediterranean. Arch Environ Contam Toxicol 39:119-123

Sanpera C, Ruiz X, Moreno R, Jover L, Waldron S (2007) Mercury and stable isotopes in feathers of Audouin's Gulls as indicators of feeding habits and migratory connectivity. Condor 109:268-275
Shaffer SA, Costa DP, Weimerskirch H (2003) Foraging effort in relation to the constraints of reproduction in free-ranging albatrosses. Funct Ecol 17:66-74

Thibault JC, Bretagnolle V, Rabouam C (1997) Cory's shearwater. BWP update. Oxford University Press, Oxford

Thompson DR, Furness RW (1989) Comparison of the levels of total and organic mercury in seabird feathers. Mar Poll Bull 20:577-579

Thompson DR, Furness RW, Barrett RT (1992) Mercury concentrations in seabirds from colonies in the northeast Atlantic. Arch Environ Contam Toxicol 23:383-389

Thompson DR, Bearhop S, Speakman JR, Furness RW (1998a) Feathers as a means of monitoring mercury in seabirds: insights from stable isotope analysis. Environ Pollut 101:193-200

Thompson DR, Furness RW, Monteiro LR (1998b) Seabirds as biomonitors of mercury inputs to epipelagic and mesopelagic marine food chains. Sci Total Environ 213:299-305

Thompson DR, Stewart FM, Furness RW (1990) Using seabirds to monitor mercury in the marine environments: the validity of conversion ratios for tissue comparisons. Mar Pollut Bull 21:339-342

Walsh PM (1990) The use of seabirds as monitors of heavy metals in the marine environment. In: Furness RW, Rainbow PS (eds) Heavy metals in the marine environment. CRC Press, Boca Raton, pp 183-204

Watanuki Y, Burger AE (1999) Body mass and dive duration in alcids and penguins. Can J Zool 77:1838-1842 